v. 14, n. 1

Vitória-ES, Jan.-Feb. 2017

p. 87 - 109 ISSN 1808-2386

DOI: http://dx.doi.org/10.15728/bbr.2017.14.1.5

\title{
Theoretical Model of Engagement in the Context of Brand Communities
}

\author{
Flávia D'albergaria Freitas ${ }^{\dagger}$ \\ Federal University of Rio de Janeiro - UFRJ \\ Victor Manoel Cunha de Almeida ${ }^{\Omega}$ \\ Federal University of Rio de Janeiro - UFRJ
}

\begin{abstract}
This essay proposes to refine the concept of consumer engagement in the context of brand communities. A comprehensive review of studies addressing the phenomenon of brand community was made. This paper follows the tradition of Marketing Research and Consumer Behavior, more specifically the perspective of cognitive psychology. The main theoretical foundation of the study is the Social Identity Theory (SIT), also incorporating relevant contributions from the perspective of Consumer Culture Theory (CCT). Therefore, this study contributes to the progress of research on the phenomenon of engagement in brand communities, proposing a theoretical model that relates engagement with its antecedents factors and reflective dimensions.
\end{abstract}

Keywords: Engagement. Participation. Brand community. Identity. Integration.

*Author for correspondence:

$\digamma$ Master in Administration by the COPPEAD Institute of Administration of the Federal University of Rio de Janeiro UFRJ.

Link: Federal University of Rio de Janeiro - UFRJ. Address: Pascoal Lemme street, 355 - University City. Rio de Janeiro - RJ - Brazil. Cep. 21941-918.

E-mail: flaviadaf@gmail.com
$\Omega$ Doctor in Administration by the COPPEAD Institute of Administration of the Federal University of Rio de Janeiro - UFRJ. Link: Federal University of Rio de Janeiro - UFRJ.

Address: Pascoal Lemme street, 355 - University City. Rio de Janeiro - RJ - Brazil. Cep. 21941-918. E-mail: valmeida@coppead.ufrj.br 


\section{INTRODUCTION}

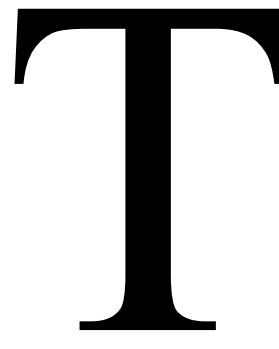

he Brand Community concept was neglected by the marketing literature until the late 90's (AMINE; SITZ, 2004). It was from the study by Muniz Jr. and O'Guinn (1996) that the concept began having greater relevance in the academia. According to these authors, the brand community is "a specialized, non-geographically bound community, based on a structured set of social relationships among admirers of a brand" (MUNIZ JR.; O'GUINN, 2001, p. 412). Or even, a brand community consists of a group of people who have a common interest in a specific brand and create a parallel universe with their own values, rituals, vocabularies and hierarchy (COVA; PACE, 2006). These people form a group of consumers who organize themselves around a lifestyle, shared activities and ethos of a brand (FOURNIER; LEE, 2009). In addition to bringing consumers and brands closer together, brand communities also act as relationship platform between its members and, therefore, they can be understood as consumer communities, a concept that predates brand communities and includes other phenomena such as tribes and subcultures consumption (MUNIZ JR.; O'GUINN, 2001).

Brand communities can be used as business strategies where one can identify and consistently communicate values that connect consumers with the brand (FOURNIER; LEE, 2009). From the company's point of view, the community allows managers to monitor the perception of consumers in real time (MCWILLIAM, 2000), encouraging them to provide feedback. In addition, these communities end up increasing the loyalty of consumers, serving as an exit barrier (MCALEXANDER; SCHOUTEN; KOENIG, 2002), and increasing purchase intent and repurchase of products (ALGESHEIMER; DHOLAKIA; HERRMANN, 2005). Other advantages would turn consumers into brand ambassadors (COVA; PACE, 2006) and work as an innovation platform, with consumers co-creating value (FÜLLER; MATZLER; HOPPE, 2008). From consumers' point of view, the community allows them to receive and share information on the brand; it serves as a form of entertainment and allows the construction of social connections (DHOLAKIA; BAGOZZI; PEARO, 2004).

Academic studies on brand communities diverge in scope. Some focus on the challenges of creating communities (MCWILLIAM, 2000; MCALEXANDER; SCHOUTEN; KOENIG, 2002; O'SULLIVAN; RICHARDSON; COLLINS, 2011; KATZ; HEERE, 2013; KATZ; HEERE, 2014), others have investigated the types of communities in relation to the different interactions between the companies holding the brand, the members who created 
them and communities (MUÑIZ JR.; SCHAU, 2005; COVA; WHITE, 2010; HOLLENBECK; ZINKHAN, 2010). We also identified studies that address the negative effects of the communities (HICKMAN; WARD, 2007).

However, the most common studies are those dealing with the relationship of community members between them and the company, the brand and the product (THOMPSON; SINHA, 2008; JANG et al., 2008; MARZOCCHI; MORANDIN; BERGAMI, 2013). These studies contemplate different forms of relationship, among these the identification (BAGOZZI; DHOLAKIA, 2006; CARLSON; SUTER; BROWN, 2008), integration (MCALEXANDER; SCHOUTEN; KOENIG, 2002; QUINN; DEVASAGAYAM, 2005), participation (DHOLAKIA; BAGOZZI; PEARO, 2004; CASALÓ; FLAVIÁN; GUINALÍU, 2008) and engagement (ALGESHEIMER; DHOLAKIA; HERRMANN, 2005).

Identification, whose theoretical foundation is based on the Social Identity Theory (SIT), and integration, which was defined and operationalized from the study by McAlexander et al. (2002), are well established concepts in the brand community literature. However, the participation and engagement concepts have been interchangeably used, as is the case in Fuller, Mazler and Hoppe (2008), that confuse the "desire to engage" with the "interest to participate". There is therefore a challenge to improve the definition of engagement, differentiating it from the concept of participation (FEITOSA; BOTELHO; LOURENÇO, 2014).

The study tackles this theoretical gap, arguing that engagement is not the plain participation or interest in participating in the community. Participation is only the behavioral dimension of engagement, which is a multidimensional construct that also encompasses cognition and emotion. It contributes, therefore, for the development of research on the engagement of the phenomenon in brand communities, more specifically by proposing a theoretical model that relates the antecedent factors with the engagement and its reflexes. For the development of the theoretical model, we conducted a comprehensive literature review on brand communities. The selection of articles was carried out from January to May 2015, by accessing seven journals bases: Proquest; Ebsco; Emerald; JStore; SageJournals; SciElo; Spell and Science Direct. Two distinct searches were conducted, one for seeking the expression "comunidade da marca" in articles in Portuguese, and another for articles in English, searching the terms "brand community" and "brand communities". We only selected articles published in reviewed academic journals containing full-text. The search resulted in the identification of 135 articles. 


\section{BRAND COMMUNITIES}

In order for a brand community to be established, three characteristics need to develop: shared consciousness; rituals and traditions; and the sense of moral responsibility. The shared consciousness is formed by the inner connection members feel towards one another and the collective sense of differentiation for those who are not from the community, being formed based on the process of legitimation of participants and the oppositional loyalty to competing brands. Rituals and traditions are vital social processes for the occurrence of reproduction and internal and external transmission of the meanings of this community, from the celebration and the sharing of stories on the brand. Finally, the sense of moral responsibility is defined as a sense of duty to the community as a whole and its members, formed from the integration and retention of members and the assistance to the use of the brand's products (MUNIZ JR.; O'GUINN, 2001).

A brand community can be typified in relation to the different dimensions: (i) geographical, which may be dispersed or concentrated, (ii) social context, the community may be rich or devoid of social context; (iii) temporality, communities may be stable or periodic; (iv) identification bases, where there may be an overlapping with other communities or social roles played by the members (MCALEXANDER; SCHOUTEN; KOENIG, 2002); (v) spatial, which can be virtual or physical; (vi) communication, which can be synchronous or asynchronous; (vii) level of participation, which, can be transactional and relational (DEVASAGAYAM; BUFF, 2008); (viii) opening, and they can be for those interested in participating or exclusive for guests only (ANDERSEN, 2005); (ix) governance, which can vary between being governed entirely by the company or entirely by the members (WIRTZ et al., 2013; JUNG; KIM; KIM, 2014; YONGJUN et al., 2010); and (x) social interaction, since these communities can be social or psychological (CARLSON; SUTER; BROWN, 2008).

As these communities are made up of people who have social identification with others who share interests with a particular brand (ALGESHEIMER; DHOLAKIA; HERRMANN, 2005), they are intentional and voluntary (MUNIZ JR.; O'GUINN, 2001). The community usually begins due to the interest in the brand and grows by building relationships among its members (JANG et al., 2008), given that the reasons for the participation in the community is the possibility of building social relationships, personal involvement with the brand and the sharing of symbolic meanings (MORANDIN; BAGOZZI; BERGAMI, 2013). Therefore, these communities typically take place around brands with strong images, threatened by competitors, with a rich and long history, involving products or services consumed more 
publicly than privately (MUNIZ JR.; O'GUINN, 2001) and which present hedonic and experiential qualities (MCALEXANDER; SCHOUTEN; KOENIG, 2002). Furthermore, normally they are brands that facilitate high involvement with consumers (MCWILLIAM, 2000) and have the ability to produce transforming experiences (MUÑIZ JR.; SCHAU, 2005).

\section{ENGAGEMENT IN THE BRAND COMMUNITY}

Consumer engagement is a behavior that goes beyond the purchase transaction, including retention and cross-buying, sales and transaction metrics, word of mouth, customer's recommendations and references, posts on the Internet and many other behaviors that influence the company and its brands (VAN DOORN et al., 2010).

Although some studies operationalize the engagement as a one-dimensional construct, Brodie et al. (2011) show, from an extensive literature review on the phenomenon, that engagement has been predominantly represented as a multidimensional concept. The authors claim that the simplicity of the one-dimensional approach does not reflect the engagements rich conceptual scope.

Patterson, Yu and Ruyter (2006), by studying consumer engagement in the context of services based on the organizational behavior literature, defined customer engagement as a multidimensional construct comprised by the dimensions: vigor, dedication, absorption and interaction. Based on these dimensions, Brodie et. al. (2011) ) suggest that the absorption represents the cognitive dimension; dedication is the emotional dimension; and vigor and interaction represent the behavioral dimension.

Further into the service context, Brodie et. al. (2011) propose the following definition for consumer engagement:

Customer engagement (CE) is a psychological state that occurs by virtue of interactive, cocreative customer experiences with a focal agent/object (e.g., a brand) in focal service relationships. It occurs under a specific set of context dependent conditions generating differing CE levels; and exists as a dynamic, iterative process within service relationships that cocreate value. (...) It is a multidimensional concept subject to a context- and/or stakeholder-specific expression of relevant cognitive, emotional and/or behavioral dimensions (BRODIE et al., 2011, p. 9).

Consumer engagement with the brand was defined by Hollebeek (2011, p. 790) as:

The level of an individual customer's motivational, brand-related and contextdependent state of mind characterized by specific levels of cognitive, emotional and behavior activity in direct brand interactions.

In line with consumer engagement definitions in services and engagement with the brand, it can be said that engagement is characterized by: (i) being a variable at the individual level; (ii) motivational; (iii) context-dependent; (iv) emerging from the interactions between 
subjects and objects; (v) with fluctuating intensity; (vi) dynamic and longitudinal in nature; and (vii) multidimensional (HOLLEBEEK, 2011); (viii) which involves a psychological state; (ix) cyclical in nature; and (x) encompassing a process of co-creation (BRODIE et al., 2011).

In the context of brand communities, engagement refers to the motivations to interact and cooperate with community members, that is, it assumes that the members are interested in helping others, participate in joint activities, act voluntarily to endorse and enhance its own value and others' (ALGESHEIMER; DHOLAKIA; HERRMANN, 2005).

There are multiple benefits and motivations for a consumer to become a member of a brand community, for example, the search for legitimacy, the recognition of peers, and social empowerment. These benefits cannot be fully achieved without a strong commitment (MARCHI; GIACHETTI; DE GENNARO, 2011). As a result of the engagement, community members develop loyalty and satisfaction; empowerment; connection and emotional ties; trust and commitment (BRODIE et al., 2013).

In the context of brand communities, we identified five engagement sub processes: (i) learning, which refers to one acquiring cognitive skills; (ii) sharing information, knowledge and experiences through active contributions; (iii) advocating in favor of the brand, actively recommending it; (iv) socializing, acquiring and developing attitudes, norms and languages; and (v) co-developing, contributing to the organization, assisting in the development processes of products, brands and brands meaning (BRODIE et al., 2013).

The engagement includes all customer-company interactions and all communications among consumers about the brand (GUMMERUS et al., 2012). Since engagement in brand communities is focused on consumers' interactive experiences (BRODIE et al., 2013), companies wishing to increase consumers engagement in the communities should foster opportunities so interpersonal relationships may occur more frequently (LEE; CHANG, 2011).

Some studies covering engagement in brand communities operationalize participation as an interchangeable concept with engagement (FÜLLER; MATZLER; HOPPE, 2008). However, consumer participation occurs by creating and delivering interactive services (BOLTON; SAXENA-IYER, 2009) and it is traditionally focused on the economic effects of the consumer's "physical" presence, while the engagement transcends physical presence, including psychological processes (PATTERSON; YU; RUYTER, 2006). Thus, the participation in the practices and rituals of a brand community is a necessary condition 
(HOLLEBEEK, 2011; VIVEK, BEATTY and MORGAN, 2012), but not sufficient for engagement. In other words, participation is a proxy for engagement.

\subsection{CONCEPTUAL MODEL}

Figure 1 shows the conceptual model proposed in this study. The model proposes the existence of a circular relationship between participation and engagement in brand communities. It further proposes the identification with the brand, the intention to participate in the community and participation as antecedent factors of engagement, which is proposed as a multidimensional construct which is reflected in the identification with the brand community, the internalization of values, in the sense of moral responsibility and degree of community member integration.

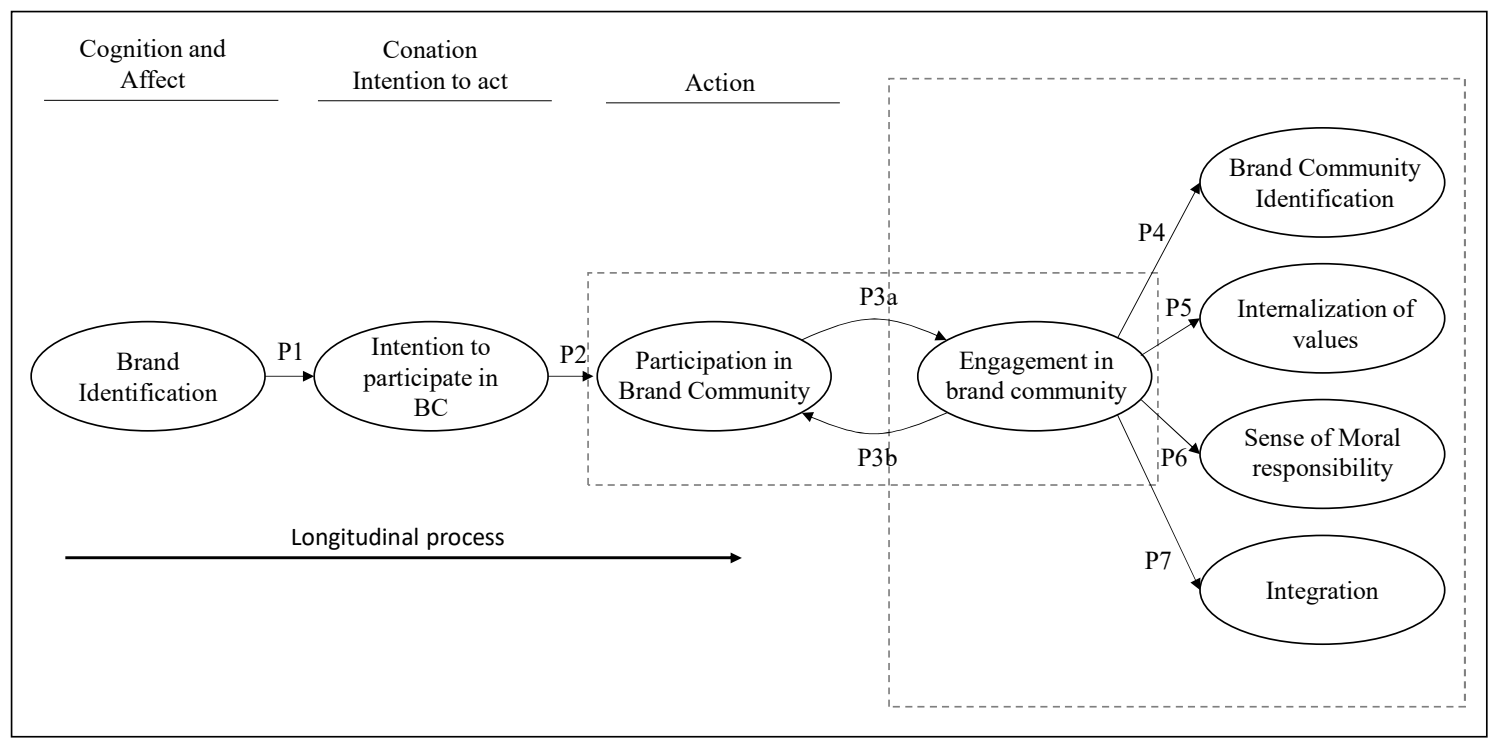

Figure 1 - Conceptual Model of Engagement in a Brand Community

Source: Elaborated by the authors.

\section{ANTECEDENTS OF ENGAGEMENT}

\subsection{BRAND IDENTIFICATION}

As suggested by the SIT, individuals have a predisposition to classify themselves and others in social categories (BAGOZZI; DHOLAKIA, 2006). People identify with things and people that share similar attributes (HASSAY; PELOZA, 2009) and with groups they perceive as relevant to their interests and personal values (BHATTACHARYA; ELSBACH, 2002). Thus, identification is defined as the extent to which the consumer sees their own image reflected in the image of the other party, that is, the identification with a brand is when the consumer sees their identity reflected in the brand's identity (BAGOZZI; DHOLAKIA, 2006; CARLSON; SUTER; BROWN, 2008). Thus, the brand identification serves as a channel for expressing the self-image, adding social value to the consumer and symbolic utility (ZHOU et al., 2011). 
The brand is at the center of the customer identification process in the context of brand communities and it directs belonging to the group. The consumer can begin a process of selfcategorization by selecting a specific brand which one identifies themselves with and by seeking other consumers that share this same passion for the brand (YEH; CHOI, 2011; ALGESHEIMER; DHOLAKIA; HERRMANN, 2005). Thus, it can be said that the consumer's relationship with the brand precedes and contributed to their relationship with this brand's community. Typically, consumers first identify value in the brand by its functional and symbolic benefits and then seek out and interact with consumers who share their enthusiasm (ALGESHEIMER; DHOLAKIA; HERRMANN, 2005). That is, the identification with the brand is a precedent for the participation and affiliation with the community (WIRTZ et al., 2013) and it facilitates the integration and identification of the consumer towards the brand community. More specifically, the relationship with the brand is an antecedent of intentions to participate in community practices (ALMEIDA et al., 2011). Thus, we propose that:

Proposition 1: The greater the brand identification, the greater the intention to participate in the brand community.

\subsection{PARTICIPATION IN THE BRAND COMMUNITY}

The participation in brand community rituals is an important factor for the development and sustainability of communities (ALGESHEIMER; DHOLAKIA; HERRMANN, 2005; CASALÓ; FLAVIÁN; GUINALÍU, 2007; CASALÓ; FLAVIÁN; GUINALÍU, 2008; MADUPU; COOLEY, 2010a), this because participation promotes interaction among members and increases the contribution that the community can provide for these members (CASALÓ; FLAVIÁN; GUINALÍU, 2008). It is through participation that the community develops and maintains itself, since members share information and experiences (CASALÓ; FLAVIÁN; GUINALÍU, 2007), increasing the understanding of the brand (BAGOZZI; DHOLAKIA, 2006), and the benefits perceived by members (KUO; FENG, 2013), which ultimately also promotes identification with the community and consequently the value of the community (CASALÓ; FLAVIÁN; GUINALÍU, 2007; CASALÓ; FLAVIÁN; GUINALÍU, 2008). In this sense, to increase participation, the community must provide opportunities for members to meet their needs, increasing their familiarity with the community and promoting communication and cohesion among group members (CASALÓ; FLAVIÁN; GUINALÍU, 2007). 
Participation is a behavior and, as such, it can be observed. In virtual communities, for example, this participation could be measured by the effort to encourage the community; by the value of comments to help other members; or by the excitement and motivation with which an individual posts a message and responds to the community (KOH; KIM, 2004). Other studies measure the intensity of participation in virtual communities through the level of participation in terms of the average frequency and the duration that reflects this presence and the level of contribution based on the number of activities of which the member participates (RAÏES; GAVARD-PERRET, 2011).

Participation in the community comprises two components: the member-member interaction and the member-activity involvement. The member-member interaction refers to the extent of interaction between members, whereas the member-activity involvement refers to the intensity at which the member participates in community activities (TSAI; HUANG; CHIU, 2012).

There are different antecedent variables for participation in a brand community, some of these variables are at the individual level and others at the group level (DHOLAKIA, BAGOZZI; PEARO, 2004; PONGSAKORNRUNGSILP; SCHROEDER, 2011). The individual variables depend on the brand community context and the motivations can be utilitarian, intellectual or of social support (ALGESHEIMER; DHOLAKIA; HERRMANN, 2005). At the group level, the influences are the identification and compliance (BAGOZZI; DHOLAKIA, 2002). Some studies highlight that individual motivations are group influences antecedents (BAGOZZI; DHOLAKIA, 2002; DHOLAKIA; BAGOZZI; PEARO, 2004).

\subsubsection{Intention to Participate and Participation}

By adopting the social psychology perspective, participation is an intentional social action; Therefore, the behavior of participation is preceded by an intention to participate. In the specific case of brand communities, the intention to participate is not a purely individual intention, it is a collective experience. The individual intention is the personal motivation to exert an effort to perform a behavior. In the case of we-intention, this motivation is formed by multiple goals shared with other individuals. In this case, the member is seen as part of a social structure. Furthermore, it is worth noting that the intention to participate includes individual determinants, as anticipated emotions and desires, and collective influences, such as the identification (BAGOZZI; DHOLAKIA, 2002). In addition, it is known that the intention to participate in virtual communities is influenced by existing posts in the community, mediated by the informational value generated by posts and by the social value 
perceived by participation. That is, the more posts visitors see in the community, the more they perceive benefits in participating, whether by the information they will have access to, or by the building of relationships that participation in the community will make possible (ZHOU et al., 2013). Thus, the social intention precedes the participation of the member in the community (DHOLAKIA; BAGOZZI; PEARO, 2004). Thus, we propose that:

Proposition 2: The greater the intention to participate, the greater the participation in the brand community.

\subsubsection{Participation and Engagement in Brand Community}

Since the engagement in the community results from the overlapping of the individual's values and the identity based on the group, the participation in the community can be understood as the manifestation of this congruence (ALGESHEIMER; DHOLAKIA; HERRMANN, 2005), being an antecedent of the engagement (BRODIE et al., 2011). Therefore, we propose that:

Proposition 3a: The greater the level of participation in the community, the greater the engagement in the brand community.

However, the engagement process presents an interactive and cyclical dynamics; thus, the relational consequences of engagement can act as an engagement antecedent in subsequent processes (BRODIE et al., 2011). This helps to understand why some studies claim that the engagement precedes participation (ALGESHEIMER; DHOLAKIA; HERRMANN, 2005). Therefore, we propose that:

Proposition 3b: The greater the engagement in the community, the greater the level of participation in the brand community.

\section{REFLECTIONS OF ENGAGEMENT}

The engagement in the brand community has resulted in the intensification of the characteristic manifestations of the brand community. The greater the engagement in the community, the greater the consciousness of kind, the greater the knowledge of rituals and traditions and the sense of moral responsibility will be, characteristics that define a community (MADUPU; COOLEY, 2010a). In addition, there will be a greater integration with the brand, product, company and with other consumers of the brand (MCALEXANDER; SCHOUTEN; KOENIG, 2002). 


\subsection{BRAND COMMUNITY IDENTIFICATION}

The consciousness of kind, one of the characteristics of brand communities (MUNIZ JR.; O'GUINN, 2001), can be interpreted as the identification with the community (BAGOZZI; DHOLAKIA, 2006). According to some authors, this is the most important characteristic in defining a community (BROGI, 2014), because it is the manifestation of the sense of "we-ness", the sense of shared belonging, that allows the differentiation and separation of who is a member and who is not member of the community (MUNIZ JR.; O'GUINN, 2001).

Whilst the identification is defined as the extent to which the consumer sees their own image reflected in the image of the other party (BAGOZZI; DHOLAKIA, 2006; CARLSON; SUTER; BROWN, 2008), the identification with the community reflects how the member agrees with the rules and community goals (LEE; CHANG, 2011). Thus, in a brand community identification can have two levels: the individual level, when there is identification with the brand; and at the collective level, when there is identification with the community (CHANG; HSIEH; TSENG, 2013). Community members can negotiate these two levels of identity, social and individual, manifesting in some cases one more over the other (SCHAU; MUNIZ JR., 2002). There are cases where this collective identity superimposes even the individual identity and is incorporated into one's daily life and way of thinking (ACOSTA; DEVASAGAYAM, 2010). The greater the consumer identification with the community, the more the consumer will act towards this identification (HEERE et al., 2011).

The identification has three components; (i) cognitive identification, when the participant knows that they belong to that community, acknowledging ones similarities to other participants; (ii) evaluative identification, when the participant realizes that they are an important and valuable member in the group; and (iii) emotional, which encompasses the emotions that the participant feels to be part of the group and the emotions that they develop in relation to other participants (MARZOCCHI; MORANDIN; BERGAMI, 2013; BAGOZZI; DHOLAKIA, 2006; ZAGLIA, 2013).

In the context of brand communities, identification can be understood as the strength of the relationship that its members have with the community and so it is a socially constructed identity (ALGESHEIMER; DHOLAKIA; HERRMANN, 2005), with the brand at the center of this consumer identification process (YEH; CHOI, 2011), resulting in a strengthening of the identification with the brand itself (STOKBURGER-SAUER, 2010). Typically, this identification is the result of the social interaction that takes place between community 
members (KATZ; HEERE, 2013), however, it can also be expressed as a psychological sense of the community, when members see themselves as part of a community (CARLSON; SUTER; BROWN, 2008). Whereas the identification with the community occurs mainly from the participation in the community (ALMEIDA et al., 2011) and that participation precedes the engagement (BRODIE et al., 2011), it is necessary to investigate whether it is directly related to the brand community identification. Thus, we propose that:

Proposition 4: The greater the engagement in the community, the greater the brand community identification.

\subsection{INTERNALIZATION OF VALUES}

Internalization occurs when the member accepts the influence of the group because this influence is congruent with its value system and the behavior induced by this influence is extremely rewarding (KELMAN, 1958).

In the context of brand community, internalization refers to the understanding and community member's commitment to the values, beliefs and conventions shared with other members, that is, the adoption of common guidelines to achieve idealized goals jointly with others (DHOLAKIA; BAGOZZI; PEARO, 2004). The internalization process evolves from the information exchanged between the members, when the member goes on to decide, based on the congruence of their values with the values of other members (BAGOZZI; DHOLAKIA, 2002).

Affiliating to the community, the member may undergo normative pressures that require implicitly to act according to rules, rituals and community goals. The influence of the group is established from subjective norms that must be accepted in private, but are manifested publicly. When the publicly visible behavior occurs at odds with private acceptance, social pressure takes place, so the higher the member's identification with the community, the lesser the normative pressure will be (ALGESHEIMER; DHOLAKIA; HERRMANN, 2005).

The internalization construct was operationalized in some studies as the effects of group norms (BAGOZZI; DHOLAKIA, 2002; DHOLAKIA; BAGOZZI; PEARO, 2004). The process by which users collectively set standards is a social construction that emerges and is developed over time. Thus, communication between group members increases with time and produces social influence, becoming normative. Based on this influence, the group norms start to regulate the interaction between the members, and the social construction process becomes prominent as it increases the interaction between the parties (POSTNES; SPEARS; LEA, 
2000). Thus, the more engaged the member is in the community, the more prominent the internalization of norms, values, shared beliefs in these groups become. Thus we propose that:

Proposition 5: The greater the engagement in the community, the greater the internalization of values, beliefs and norms shared in the brand community.

\subsection{SENSE OF MORAL RESPONSIBILITY}

Brand communities presuppose a moral responsibility from its members, that is, the sense of duty to the community itself and with other members. Some of the members' duties of a brand community include the provision of assistance in the integration and retention of members for the correct use of the brand (MUNIZ JR.; O'GUINN, 2001), the community may even eliminate members that do not exhibit appropriate behavior (MCWILLIAM, 2000). This sense of responsibility can be defined as the psychological sense of community, capturing a type of connection that goes beyond the identification and attraction (HASSAY; PELOZA, 2009).

In a brand community there is heterogeneity of roles and hierarchies among members (OUWERSLOOT; ODEKERKEN-SCHRÖDER, 2008), it is so because some characteristics of members emphasize the influence of some over others, including the time of participation and the level of participation (ALGESHEIMER; DHOLAKIA; HERRMANN, 2005). The degree of influence in a community affects the participation of members (WOISETSCHLÄGER; HARTLEB; BLUT, 2008), and the oldest and most influential members play important roles in communities. They are responsible, for example, for reducing regulatory pressures (ALGESHEIMER; DHOLAKIA; HERRMANN, 2005). The practices provide participants with cultural capital, which offer the opportunity for individual differentiation. The competition for this cultural capital, distinguishes the members creating a social hierarchy (SCHAU; MUÑIZ JR.; ARNOULD, 2009). There are members who assume the dominant roles, serving as hubs in the social network formed in the community are the leaders (KATZ; HEERE, 2013). With that, the higher the engagement in the community, the greater the sense of moral responsibility. Thus we propose that:

Proposition 6: The greater the engagement in the community, the greater the sense of moral responsibility that the member has with other community members.

\subsection{INTEGRATION}

Community members show enthusiasm in sharing their views (MCWILLIAM, 2000), and integration in a brand community is a function of the perceived relationship of a 
consumer with the product, the brand, the company and other consumers (MCALEXANDER; SCHOUTEN; KOENIG, 2002). Through integration, consumers provide feedback to companies and enables learning in relation to products (MCALEXANDER; SCHOUTEN; KOENIG, 2002).

The integration of community members has personal and social motivations. Selfrelated motivations (personal) are: (i) knowledge, interest in learning more about how the product works; (ii) pleasure, joy that encourages the person to be a member of the community; (iii) self-esteem, interest to create and maintain a positive self-concept in relation to the participation in the community. From the social point of view, the factors that motivate consumers are affiliation, interest in having relationships with others within the community and the interest to obtain social status among the other members of the community (SUKOCO; WU, 2010).

Integration can be a more powerful loyalty building tool than satisfaction, that is because through the relationship it is possible to develop links between the members and strengthen the appreciation for the brand, product and company, thus strengthening loyalty (MCALEXANDER; KIM; ROBERTS, 2003). However, it has also been suggested that integration affects satisfaction directly as a result of long-term relationships provided by integration in the community, resulting in a higher level of customer satisfaction (MILLÁN; DÍAZ, 2014).

To engage the consumer in the practices of the community strengthens the integration of the consumer with the brand, product, company and other consumers (STOKBURGERSAUER, 2010). Thus we propose that:

Proposition 7: The greater the engagement in the community, the greater the integration of the member with the brand, product, company and other members of the brand community.

\section{FINAL CONSIDERATIONS}

Understanding engagement is relevant because this construct has awakened the interest of companies and consultancies, appearing a strategic imperative. The engagement strengthens corporate performance; creates competitive advantage; increases profitability; it plays a central role in viral marketing activities; it plays an important role in the development of new products and services and co-creation (BRODIE et al., 2011). 
Engagement is a form of relationship that is being addressed in most studies on brand communities. However, it is clear that this is a concept that still lacks an unified definition accepted by the academic community. Different authors define engagement in different ways, using different scales for measuring the construct. In addition, in the brand community literature, the concept of engagement is used interchangeably with the term participation.

When we look beyond the context of brand community, we identify studies that conceptualize engagement as a distinct construct of participation itself (VAN DOORN et al., 2010; BRODIE et al., 2011; HOLLEBEEK, 2011). Participation in service encounters, for example, is the involvement that occurs in the production and service delivery, focusing on the economic aspect and the physical presence of the consumer, while the engagement goes beyond this physical presence, as it is a psychological process (PATTERSON; YU; RUYTER, 2006).

Participation represents the behavioral dimension of engagement, which is a multidimensional construct, which also comprises cognition and emotion. It is by feed backing attitude dimensions that the participation materializes the engagement, i.e., participation in rituals of brand community is the concrete instance (visible, observable) of engagement. It is for this reason that many studies take these two constructs as interchangeable, even from the point of view of measurement.

According to the model proposed in this study, participation in the brand community precedes the engagement, in other words, it is a necessary but not sufficient condition for the engagement - without participation in the brand community there is no possibility of engagement. However, longitudinally, the engagement promotes participation, setting up a circular relationship between these two constructs.

Engagement is a psychological phenomenon, an abstract construct that cannot be observed directly. However, the level of individual engagement with the brand community can be inferred by observing the various reflections of engagement, as is the case of the identification with the community, internalization of values, sense of social responsibility and integration. For example, as an individual's engagement increases, so does their identification with the brand community. One cannot say that the integration with it antecedes engagement; it develops simultaneously and circumferentially in relation to it. Thus, it is postulated that engagement is a second-order construct, and identification with the brand community, a firstorder construct. 
The objective of this article was to show in the context of brand communities that the participation and engagement constructs are different and that this misunderstanding needs to be fixed. In this sense, the proposed model aims at highlighting how these constructs are related, especially highlighting the antecedents of engagement behavior and its impact on brand communities.

\subsection{SUGGESTED FUTURE RESEARCH}

The conceptual model proposed in this study and their research proposals can be used in future research. To this end, it is necessary to validate and test the model propositions. The first step would be to validate through qualitative studies the interactions between the constructs. The next step would be the development of a multidimensional scale that can be used to measure the engagement in the context of brand communities. Finally, a quantitative study could test the model and the substantive hypotheses derived from the propositions.

In addition, a literature review allowed us to identify that although the concept of brand engagement was initially operated by Algesheimer et al. (2005) in a study that investigated the brand communities of admirers of cars, all studies that took place in the context of brand community and addressed the engagement focused on brand communities of virtual nature. In other words, they researched brand communities mediated by computer. However, many of the social interactions occur outside the virtual environment, which may represent an opportunity for further study of brand communities of this nature, especially when one perceives that the virtual and offline communities may differ in terms of how this interaction takes place; geographical and temporal dimensions; the cost that members incur; and the engagement with the brand, company and community (WIRTZ et al., 2013).

Nevertheless, the literature review on brand community identified that there are few studies on brand communities in Brazil. Only eight studies were identified that focused on cases of the Coca-Cola brand (FREITAS; LEÃO, 2010; FREITAS; LEÃO, 2012; ABDALA; BRAVO, 2011), XBox (ALMEIDA et al., 2011; ALMEIDA et al., 2012; ALMEIDA et al., 2013), diButeco food contest (ADADE; BARROS, 2013) and communities of Guaraná Antarctica and the OMO washing powder (FEITOSA; BOTELHO; LOURENÇO, 2014). As the brand communities are sensitive to cultural differences between countries (HONGMIN; MIN WOO; YONGJUN, 2010; MADUPU; COOLEY, 2010b), there is room for further study of the phenomenon in Brazil. 


\section{CONTRIBUTIONS BY THE AUTHORS}

Flávia D'albergaria Freitas is the lead author. She contributed to the development of the theoretical model, literature review and article writing.

Victor Manoel Cunha de Almeida contributed to the development of the theoretical model and was responsible for guidance at all stages of the research.

\section{REFERENCES}

ABDALA, M. M.; BRAVO, I. G. "Eu odeio Coca-Cola": Uma aAnálise Netnográfica sobre o discurso antimarca da comunidade virtual do Orkut. Revista eletrônica Estrat Neg, Florianópolis, v. 4, n. 2, p. 61-86, 2011.

ACOSTA, P. M.; DEVASAGAYAM, R. A. J. Brand Cult: Extending the Notion of Brand Communities. Marketing Management Journal, v. 20, n. 1, p. 165-176, 2010.

ADADE, D. R.; BARROS, D. F. Uma investigação sobre a Comunidade de Marca do Concurso Comida Di Buteco. Revista ADM.MADE, v. 17, n. 3, p. 127-148, 2013.

ALGESHEIMER, R.; DHOLAKIA, U. M.; HERRMANN, A. The Social Influence of Brand Community: Evidence from European Car Clubs. Journal of Marketing, v. 69, n. 3, p. 19$34,2005$.

ALMEIDA, S. O. D. et al. Os efeitos da participação em comunidades virtuais de marca no comportamento do consumidor: proposição e teste de um modelo teórico. Rev. adm. contemporânea, v. 15, n. 3, p. 366-391, 2011.

ALMEIDA, S. O. D. et al. Efeitos da comunidade de origem no participante de comunidades virtuais de marca. Revista de Administração de Empresas, v. 52, n. 2, p. 204-216, 2012.

ALMEIDA, S. O. D. et al. Participant Diversity and Expressive Freedom in Firm-Managed and Customer-Managed Brand Communities. BAR - Brazilian Administration Review, v. 10, n. 2, p. 195-218, 2013.

AMINE, A.; SITZ, L. How does a virtual brand community emerge? Some implications for marketing research. Ensomar Conference, Warsaw, Poland, 2004.

ANDERSEN, P. H. Relationship marketing and brand involvement of professionals through web-enhanced brand communities: The case of Coloplast. Industrial Marketing

Management, v. 34, n. 1, p. 39-51, 2005.

BAGOZZI, R. P.; DHOLAKIA, U. M. Intentional Soacial Action in Virtual Communities. Journal og Interactive Marketing, v. 16, n. 2, p. 2 - 21, 2002.

BAGOZZI, R. P.; DHOLAKIA, U. M. Antecedents and purchase consequences of customer participation in small group brand communities. International Journal of Research in Marketing, v. 23, n. 1, p. 45-61, 2006. 
BHATTACHARYA, C.; ELSBACH, K. Us versus them: The roles of organizational identification and disidentification in social marketing initiatives. Journal of Public Policy \& Marketing, v. 21, n. 1, p. 26-36, 2002.

BOLTON, R.; SAXENA-IYER, S. Interactive Services: A Framework, Synthesis and Research Directions. Journal of Interactive Marketing, v. 23, p. 91-104, 2009.

BRODIE, R. J. et al. Customer Engagement: Conceptual Domain, Fundamental Propositions, and Implications for Research. Journal of Service Research, p. 1-20, 2011.

BRODIE, R. J. et al. Consumer engagement in a virtual brand community: An exploratory analysis. Journal of Business Research, v. 66, n. 1, p. 105-114, 2013.

BROGI, S. Online Brand Communities: A Literature Review. Procedia - Social and Behavioral Sciences, v. 109, p. 385-389, 2014.

CARLSON, B. D.; SUTER, T. A.; BROWN, T. J. Social versus psychological brand community: The role of psychological sense of brand community. Journal of Business Research, v. 61, n. 4, p. 284-291, 2008.

CASALÓ, L. V.; FLAVIÁN, C.; GUINALÍU, M. The impact of participation in virtual brand communities on consumer trust and loyalty: The case of free software. Online Information Review, v. 31, n. 6, p. 775-792, 2007.

CASALÓ, L. V.; FLAVIÁN, C.; GUINALÍU, M. Promoting Consumer's Participation in Virtual Brand Communities: A New Paradigm in Branding Strategy. Journal of Marketing Communications, v. 14, n. 1, p. 19-36, 2008.

CHANG, A.; HSIEH, S. H.; TSENG, T. H. Online Brand Community Response to Negative Brand Events: The Role of Group eWOM. Internet Research , v. 23, n. 4, 2013.

COVA, B.; PACE, S. Brand community of convenience products: new forms of customer empowerment - the case "my Nutella The Community". European Journal of Marketing, v. 40, n. 9/10, p. 1087-1105, 2006.

COVA, B.; WHITE, T. Counter-brand and alter-brand communities: the impact of Web 2.0 on tribal marketing approaches. Journal of Marketing Management, v. 26, n. 3-4, p. 256$270,2010$.

DEVASAGAYAM, P. R.; BUFF, C. L. A Multidimensional Conceptualization of Brand Community: An Empirical Investigation. Sport Marketing Quarterly, v. 17, n. 1, p. 20-29, 2008.

DHOLAKIA, U. M.; BAGOZZI, R. P.; PEARO, L. K. A social influence model of consumer participation in network- and small-group-based virtual communities. Intern. J. of Research in Marketing, v. 21, p. 241-263, 2004.

FEITOSA, W. R.; BOTELHO, D.; LOURENÇO, C. E. Comunidades virtuais de marca de produtos de consumo e criação de engajamento: uma investigação qualitativa. Revista Eletrônica Gestão e Serviços, v. 5, n. 1, p. 827-848, 2014. 
FOURNIER, S.; LEE, L. Getting brand communities right. Harvard Business Review, v. 87, n. 4, 2009.

FREITAS, G. K. A. D.; LEÃO, A. L. M. D. S. Atividades Marcárias Como Recursos de Elaboração da Face em Comunidades Virtuais de Marca: Análise de uma Comunidade Virtual de Consumidores da Coca-Cola. Revista Brasileira de Marketing, v. 9, n. 2, p. 85-112, 2010 .

FREITAS, G. K. A. D.; LEÃO, A. L. M. D. S. A elaboração da face em comunidades virtuais de marca: um estudo de caso sobre uma comunidade virtual de consumidores de Coca-Cola. Cadernos EBAPE.BR, v. 10, n. 1, p. 181-201, 2012.

FÜLLER, J.; MATZLER, K.; HOPPE, M. Brand Community Members as a Source of Innovation. Journal of Product Innovation Management, v. 25, n. 6, p. 608-619, 2008.

GUMMERUS, J. et al. Customer engagement in a Facebook brand community. Management Research Review, v. 35, n. 9, p. 857-877, 2012.

HASSAY, D. N.; PELOZA, J. Building the Charity Brand Community. Journal of Nonprofit \& Public Sector Marketing, v. 21, n. 1, p. 24-55, 2009.

HEERE, B. et al. Brand Community Development Through Associated Communities: Grounding Community Measurement Within Social Identity Theory. Journal of Marketing Theory \& Practice, v. 19, n. 4, p. 407-422, 2011.

HICKMAN, T.; WARD, J. The Dark Side of Brand Community: Inter-Group Stereotyping, Trash Talk, and Schadenfreude. Advances in Consumer Research, v. 34, p. 314-319, 2007.

HOLLEBEEK, L. D. Demystifying customer brand engagement: Exploring the loyalty nexus. Journal of Marketing Management, v. 27, n. 7-8, p. 785 - 807, 2011.

HOLLENBECK, C. R.; ZINKHAN, G. M. Anti-brand communities, negotiation of brand meaning, and the learning process: The case of Wal-Mart. Consumption Markets and Culture, v. 13, n. 3, p. 325-345, 2010.

HONGMIN, A.; MIN WOO, K.; YONGJUN, S. Online Brand Community across Cultures. International Journal of e-Business Management, v. 4, n. 1, p. 34-52, 2010.

JANG, H. et al. The Influence of On-Line Brand Community Characteristics on Community Commitment and Brand Loyalty. International Journal of Electronic Commerce, v. 12, n. 3, p. 57-80, 2008.

JUNG, N. Y.; KIM, S.; KIM, S. Influence of consumer attitude toward online brand community on revisit intention and brand trust. Journal of Retailing and Consumer Services, v. 21, n. 4, p. 581-589, 2014.

KATZ, M.; HEERE, B. Leaders and Followers: An Exploration of the Notion of Scale-Free Networks Within a New Brand Community. Journal of Sport Management, v. 24, n. 7, p. 271-287, 2013.

KATZ, M.; HEERE, B. Empowerment within brand communities: Overcoming the Achilles' Heel of scale-free networks. Sport Management Review, 2014. 
KELMAN, H. C. Compliance, identification, and internalization: Three processes of attitude change. Journal of Conflict Resolution, v. 2, n. 1, p. 51-60, 1958.

KOH, J.; KIM, Y.-G. Knowledge sharing in virtual communities: an e-business perspective. Expert Systems with Applications, v. 26, p. 155-166, 2004.

KUO, Y.-F.; FENG, L.-H. Relationships among community interaction characteristics, perceived benefits, community commitment, and oppositional brand loyalty in online brand communities. International Journal of Information Management, v. 33, n. 6, p. 948-962, 2013.

LEE, Y.-H.; CHANG, W.-L. The effect of interpersonal relationships on brand community. International Journal of Digital Content Technology and its Applications, v. 5, n. 7, p. 297-305, 2011.

MADUPU, V.; COOLEY, D. O. Antecedents and Consequences of Online Brand Community Participation: A Conceptual Framework. Journal of Internet Commerce, v. 9, n. 2, p. 127 147, 2010a.

MADUPU, V.; COOLEY, D. O. Cross-Cultural Differences in Online Brand Communities: An Exploratory Study of Indian and American Online Brand Communities. Journal of International Consumer Marketing, v. 22, n. 4, p. 363-375, $2010 \mathrm{~b}$.

MARCHI, G.; GIACHETTI, C.; DE GENNARO, P. Extending lead-user theory to online brand communities: The case of the community Ducati. Technovation, v. 31, n. 8, p. 350$361,2011$.

MARZOCCHI, G.; MORANDIN, G.; BERGAMI, M. Brand communities: loyal to the community or the brand? European Journal of Marketing, v. 47, n. 1/2, p. 93-114, 2013.

MCALEXANDER, J. H.; KIM, S. K.; ROBERTS, S. D. Loyalty: the Influence of Satisfaction and Brand Community Integration. Journal of Marketing Theory \& Practice, v. 11, n. 4, p. $1-11,2003$.

MCALEXANDER, J. H.; SCHOUTEN, J. W.; KOENIG, H. F. Building Brand Community. Journal of MArketing, v. 66, n. January, p. 38-54, 2002.

MCWILLIAM, G. Building Strong Brands through Online Communities. Sloan Management Review, v. 41, n. 3, p. 43-54, 2000.

MILLÁN, Á.; DÍAZ, E. Analysis of consumers' response to brand community integration and brand identification. Journal of Brand Management, v. 21, n. 3, p. 254-272, 2014.

MORANDIN, G.; BAGOZZI, R. P.; BERGAMI, M. Brand community membership and the construction of meaning. Scandinavian Journal of Management, v. 29, n. 2, p. 173-183, 2013.

MUNIZ JR, A. M.; O'GUINN, T. C. Brand Community. Journal of Consumer Reserach, v. 27, n. 4, p. 412-432, 2001. 
MUNIZ JR, A. M.; O'GUINN, T. C. Brand Community and the Sociology of Brands. In: LYNCH, K. P. C. A. J. G. Advances in Consumer Research. [S.1.]: [s.n.], v. 23, 1996. p. 265-267.

MUÑIZ JR., A. M.; SCHAU, H. J. Religiosity in the Abandoned Apple Newton Brand Community. Journal of Consumer Research, v. 31, n. Março, p. 737-747, 2005.

O'SULLIVAN, S. R.; RICHARDSON, B.; COLLINS, A. How brand communities emerge: The Beamish conversion experience. Journal of Marketing Management, v. 27, n. 9/10, p. 891-912, 2011.

OUWERSLOOT, H.; ODEKERKEN-SCHRÖDER, G. Who's who in brand communities and why? European Journal of Marketing, v. 42, n. 5/6, p. 571-585, 2008.

PATTERSON, P.; YU, T.; RUYTER, K. D. Understanding Customer Engajement in Services. Advancing Theory, Maintaining Relevance, Proceedings of ANZMAC 2006 Conference, 4-6 December 2006.

PONGSAKORNRUNGSILP, S.; SCHROEDER, J. E. Understanding value co-creation in a co-consuming brand community. Marketing Theory, v. 11, n. 3, p. 303-324, 2011.

POSTNES, T.; SPEARS, R.; LEA, M. The formation of group norms in Computer-Mediated Communication. Human Communication Research, v. 26, n. 6, p. 341 - 371, 2000.

QUINN, M.; DEVASAGAYAM, R. Building brand community among ethnic diaspora in the USA: Strategic implications for marketers. Journal of Brand Management, v. 13, n. 2, p. 101-114, 2005.

RAÏES, K.; GAVARD-PERRET, M.-L. Brand Loyalty Intention Among Members of a Virtual Brand Community: the Dual Role of Commitment. Recherche et Applications en Marketing (English Edition), v. 26, n. 3, p. 23-41, 2011.

SCHAU, H. J.; MUNIZ JR, A. M. Brand Communities and Personal Identities: Negotiations in Cyberspace. Advances in Consumer Research, v. 29, n. 1, p. 344-349, 2002.

SCHAU, H. J.; MUÑIZ JR., A. M.; ARNOULD, E. J. How Brand Community Practices Create Value. Journal of Marketing, v. 73, n. September, p. 30-51, 2009.

STOKBURGER-SAUER, N. Brand community: Drivers and outcomes. Psychology \& Marketing, v. 27, n. 4, p. 347-368, 2010.

SUKOCO, B. M.; WU, W.-Y. The personal and social motivation of customers' participation in brand community. African Journal of Business Management, v. 4, n. 5, p. 614-622, 2010 .

THOMPSON, S. A.; SINHA, R. K. Brand Communities and New Product Adoption:The Influence and Limits of Oppositional Loyalty. Journal of Marketing, v. 72, n. 6, p. 65-80, 2008.

TSAI, H.-T.; HUANG, H.-C.; CHIU, Y.-L. Brand community participation in Taiwan: Examining the roles of individual-, group-, and relationship-level antecedents. Journal of Business Research, v. 65, n. 5, p. 676-684, 2012. 
VAN DOORN, J. et al. Customer Engagement Behavior: Theoretical Foundations and Research Directions. Journal of Service Research, v. 13, n. 3, p. 253-266, 2010.

VIVEK, S. D.; BEATTY, S. E.; MORGAN, R. M. Customer Engagement: Exploring Customer Relationships Beyond Purchase. Journal of Marketing Theory and Practice, v. 20, n. 2, p. 127-145, 2012.

WIRTZ, J. et al. Managing brands and customer engagement in online brand communities. Journal of Service Management , v. 24, n. 3, p. 223-244, 2013.

WOISETSCHLÄGER, D. M.; HARTLEB, V.; BLUT, M. How to Make Brand Communities Work: Antecedents and Consequences of Consumer Participation. Journal of Relationship Marketing, v. 7, n. 3, p. 237-256, 2008.

YEH, Y.-H.; CHOI, S. M. MINI-lovers, maxi-mouths: An investigation of antecedents to eWOM intention among brand community members. Journal of Marketing

Communications, v. 17, n. 3, p. 145-162, 2011.

YONGJUN, S. et al. An Explorative Study of Korean Consumer Participation in Virtual Brand Communities in Social Network Sites. Journal of Global Marketing, v. 23, n. 5, p. 430-445, 2010.

ZAGLIA, M. E. Brand communities embedded in social networks. Journal of Business Research, v. 66, n. 2, p. 216-223, 2013.

ZHOU, Z. et al. How do brand communities generate brand relationships? Intermediate mechanisms. Journal of Business Research, v. 65, n. 7, p. 890-895, 2011.

ZHOU, Z. et al. Transforming visitors into members in online brand communities: Evidence from China. Journal of Business Research, v. 66, n. 12, p. 2438-2443, 2013. 
BBR, Braz. Bus. Rev. (Engl. ed., Online), 